\title{
Development of Neuropeptide Drugs that Cross the Blood-Brain Barrier
}

\author{
Richard D. Egleton and Thomas P. Davis \\ Department of Medical Pharmacology, University of Arizona College of Medicine, Tucson, Arizona 85724
}

\begin{abstract}
Summary: In recent years, there have been several important advancements in the development of neuropeptide therapeutics. Nevertheless, the targeting of peptide drugs to the CNS remains a formidable obstacle. Delivery of peptide drugs is limited by their poor bioavailability to the brain due to low metabolic stability, high clearance by the liver, and the presence of the blood brain barrier (BBB). Multiple strategies have been devised in an attempt to improve peptide drug delivery to the brain, with variable results. In this review, we discuss several of
\end{abstract}

the strategies that have been used to improve both bioavailability and BBB transport, with an emphasis on antibody based vector delivery, useful for large peptides/small proteins, and glycosylation, useful for small peptides. Further development of these delivery methods may finally enable peptide drugs to be useful for the treatment of neurological disease states. Key Words: Blood brain barrier peptide transport/antibody based vectors/transferrin receptor/glycopeptides.

\section{INTRODUCTION}

The role of neuropeptides in disease has become an important area of research over the past two decades. Neuropeptides have been indicated as primary molecules in several neurological disorders including epilepsy and depression (see Table 1). The use of peptides as pharmacological agents is an attractive proposition due to low toxicity of their metabolites and enhanced potency. Despite the growth in understanding of neurological disorders, peptide-based therapeutics are not currently available for treating these clinical problems. This is largely due to inadequate delivery of intact/viable peptides to specific brain regions necessary for neurological disease treatment. The delivery of peptide-based drugs to the brain is limited by two main factors; general bioavailability issues and the presence of the blood brain barrier (BBB).

The bioavailability of pharmaceuticals to the brain can be affected by a number of factors. These include distribution within the cardiovascular space, total volume of distribution, half-life of disappearance, and the ability of the drug to reach the target for biological effects. The

Address correspondence and reprint requests to Richard D. Egleton, Ph.D., Department of Medical Pharmacology, University of Arizona College of Medicine, P.O. Box 245050, Tucson, AZ 85724. E-mail: rde@email.arizona.edu. contribution of each of these components is different for each drug, and for peptide neuropharmaceuticals each should be considered a potential problem for drug delivery. The cardiovascular compartment can be split into three fractions: blood cells (predominantly red blood cells), protein fraction, and protein-free fraction (PFF). The PFF contains the peptide drug available at a particular time for transport into the brain. The distribution of peptide within these three compartments is in a dynamic equilibrium. In general the equilibrium is driven to release peptide to the PFF because this pool is constantly depleted by enzymatic metabolism, excretion, and uptake (Figure 1). For peptides, this cardiovascular compartment is of particular importance. Most peptide neuropharmaceuticals are analogs of endogenous peptides and as such can interact with both carrier proteins and endogenous peptidases. It is important to note that levels of these proteins and enzymes can be regulated/altered by disease, and are also species dependent. Insulin-like growth factor (IGF)-1, a 70-amino acid peptide, has a number of different binding sites within plasma and each has differing binding constants. ${ }^{1}$ The level of one IGF binding protein has been shown to be regulated by IGF levels, as well as disease state ${ }^{2}$.

There are a number of endogenous peptidases, both in the serum and on blood vessels that metabolize peptides efficiently (Table 2). Peptidases such as aminopeptidase 
TABLE 1. Potential Targets for Peptide-Based Therapies

\begin{tabular}{llc}
\hline Disease & \multicolumn{1}{c}{ Peptide } & Reference \\
\hline Pain & Opioid peptides & 111 \\
& Neurokinins & 112,113 \\
Depression & CRH & 114,115 \\
& Substance P & 116 \\
Epilepsy & Neuropeptide Y & 117 \\
& Dynorphins & 118 \\
Learning & Somatostatin & 119 \\
Obesity & Neurotrophins & 120,121 \\
& Leptin & 122 \\
Sleep & Ghrelin & 123 \\
Stroke & CRH & 124 \\
Brain cancer & BDNF & 125 \\
\hline
\end{tabular}

$\mathrm{CRH}=$ corticotropin-releasing hormone.

A are present in serum ${ }^{3}$ and can demonstrate variable concentrations dependant on clinical conditions. For example, aminopeptidase A is at higher levels in pregnant women than in nonpregnant women. ${ }^{3}$ To further complicate matters, there is a difference in both the activity and amount of serum proteolytic enzymes dependent on species, resulting in differential metabolism of both peptide and nonpeptide drugs. ${ }^{4,5}$ The metabolic stability of bradykinin and [des-Arg9] bradykinin in serum show marked species difference. ${ }^{6}$ There is also evidence for

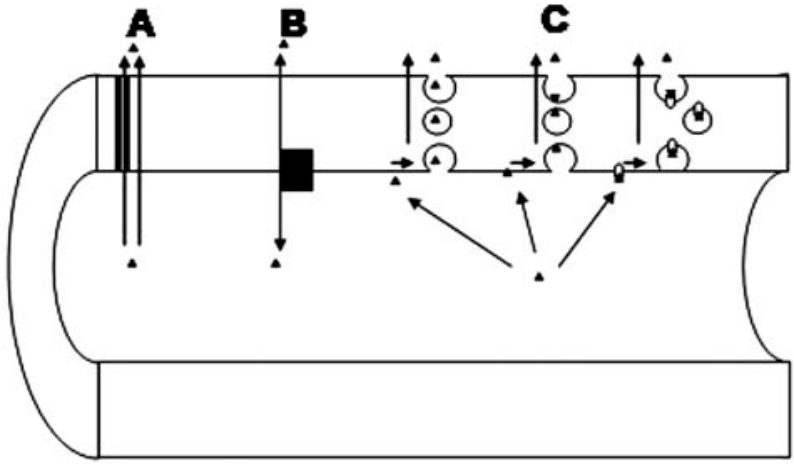

FIG. 2. The main types of transport systems that can be targeted for BBB delivery. $\mathrm{A}=$ free diffusion; $\mathrm{B}=$ carrier-mediated transport; $\mathrm{C}=$ receptor-mediated transport (see Table 3).

species differences in the renin-angiotensin enzymatic system. ${ }^{4}$

The BBB also limits the delivery of peptides to the brain. The BBB is situated at the level of the endothelial cells of the brain microvascular capillaries. ${ }^{7}$ BBB endothelial cells are connected by tight cellular junctions, which provide a high transendothelial electrical resistance of $2000 \Omega . \mathrm{cm}^{2}$, compared with 3-30 $\Omega . \mathrm{cm}^{2}$ in peripheral vessels. ${ }^{8,9}$ The BBB endothelial cells have a low number of vesicles, ${ }^{10}$ indicating reduced vesicular transport. The BBB also lacks fenestrations and is ensheathed by astrocytic end-feet, which provide autocrine

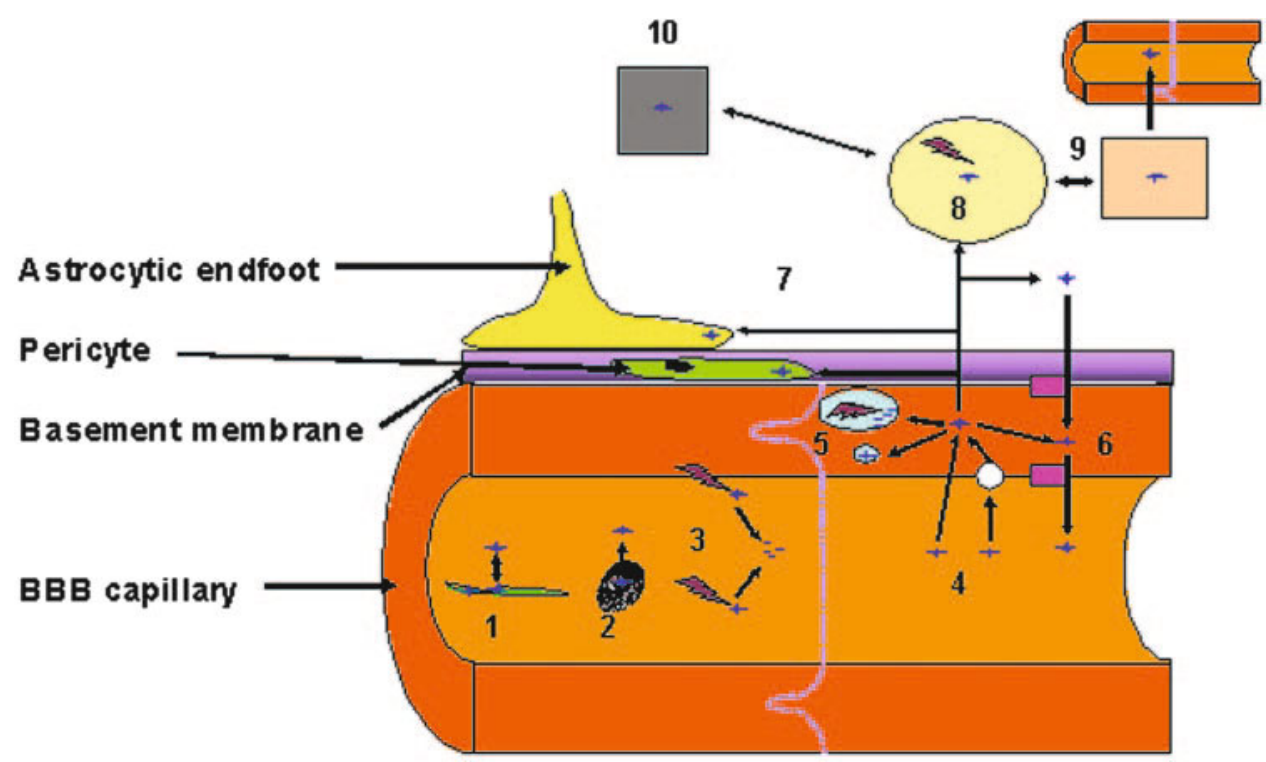

FIG. 1. Obstacles for peptide delivery to the brain. Delivery of peptides to the brain can be affected by a number of processes. Peptide drugs can bind to carrier proteins within the blood (1) or can enter the blood cells (2). These processes are in equilibrium, and the release of peptides from these two compartments is dependant on the "off" and "on" rates of the carrier protein. Peptides within these compartments may not be available for delivery to the brain. Another factor which can affect the delivery of peptides is the large number of metabolizing enzymes located in the endothelial cells and also in the plasma (3) (see Table 2). Peptides can enter the endothelial cells of the BBB (4) via simple diffusion or via a number of saturable transport mechanisms (see FIG. 2 and Table 3). Once in the endothelial cell the peptide can cross the cell, enter one of the cell compartments where it is either stored or metabolized (5), or be effluxed from the cell via one of the many energy dependent transporters at the BBB (6) (see FIG. 2). On the brain side of the BBB, the peptide can be taken up by nontarget cells such as pericytes and astrocytes (7), both of which are intimately associated with the endothelial cells. In the brain extracellular fluid (ECF) (8), the peptides can freely diffuse to the CSF and thus be re absorbed or effluxed back into the blood (9). Finally if any of the peptide is left, it can interact with the target cell/receptor (10). 
TABLE 2. Enzymes at the BBB

\begin{tabular}{llc}
\hline Enzyme & \multicolumn{1}{c}{ Example of Action } & Reference \\
\hline Dopa-decarboxylase & L-DOPA to dopamine & 128 \\
Monoamine oxidase-B & Inactivates catecholamines & 129 \\
Pseudocholinesterase & Deacetylates heroin to morphine & 130 \\
Cytochrome P450 (various) & O-Demethylates codeine to morphine & $131-133$ \\
UDP-glucuronsyltransferase & Metabolizes 1-napthol \\
Epoxide hydrolase & Reacts with epoxides \\
Renin & Angiotensinogen to angiotensin-1 \\
Dipeptidyl dipeptidase & Peptide metabolism & 134 \\
ACE & Angiotensin conversion \\
Aminopeptidase A & Peptide metabolism \\
Aminopeptidase M & Peptide metabolism \\
Glutamyl aminopeptidase & Peptide metabolism \\
Neutral endopeptidase 24.11 & Peptide metabolism \\
Endopeptidase 24.15 & Peptide metabolism \\
$\gamma$-Glutamyltranspeptidase & Leukotriene C4 to D4 \\
Alkaline phosphatase & Purine and pyrimidine metabolism & 135,137 \\
\hline
\end{tabular}

$\mathrm{UDP}=$ uridine diphosphate; $\mathrm{ACE}=$ angiostensin-converting enzyme.

factors to maintain $\mathrm{BBB}$ function. ${ }^{11}$ Additionally, the $\mathrm{BBB}$ acts as a metabolic barrier possessing a number of proteolytic enzymes ${ }^{12,13}$ including aminopeptidase $\mathrm{A},{ }^{14}$ aminopeptidase $\mathrm{M},{ }^{15}$ and angiotensin-converting enzyme $^{14}$ that are known to degrade neuropeptides. Enzymes such as $\gamma$-glutamyl transpeptidase, alkaline phos- phosphatase, and monoamine oxidase have elevated levels in brain microvessels and are either absent or expressed at low levels in peripheral vessels. ${ }^{16-18}$

The BBB plays an important role in brain homeostasis and a number of transport systems are present that enable substances to enter the brain. Specific transport systems

TABLE 3. Main Types of Transport Systems for Targeted Delivery of Peptides across the BBB

\begin{tabular}{|c|c|c|c|}
\hline Mechanism & Characteristics & Example & Reference \\
\hline \multicolumn{4}{|c|}{ 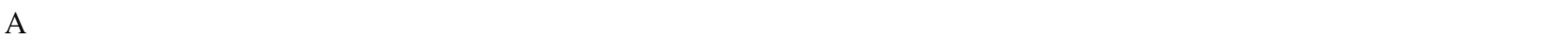 } \\
\hline Diffusion & $\begin{array}{l}\text { Flux down an electrochemical gradient } \\
\text { Energy independent } \\
\text { Flux proportional to concentration } \\
\text { Rate independent of action }\end{array}$ & CTAP (transcellular) & 144 \\
\hline \multicolumn{4}{|c|}{ 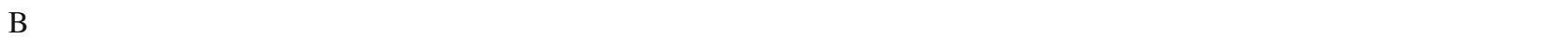 } \\
\hline Facilitated & $\begin{array}{l}\text { Carrier mediated } \\
\text { Flux is saturated by increasing concentration } \\
\text { Competitive substrates } \\
\text { Flux may be asymmetric }\end{array}$ & Biphalin via LNAA & 64 \\
\hline Active carrier mediated & $\begin{array}{l}\text { Flux can be against electrochemical gradient } \\
\text { Energy dependent (directly or indirectly) } \\
\text { Substrate specificity, saturation, competition } \\
\text { Flux rate is asymmetric }\end{array}$ & $\begin{array}{l}\beta \text {-Endorphin efflux via } \\
\text { P-glycoprotein }\end{array}$ & 53 \\
\hline \multicolumn{4}{|l|}{$\mathrm{C}$} \\
\hline Endocytosis & $\begin{array}{l}\text { Invagination of plasma membrane to form an internalized } \\
\text { membrane vesicle } \\
\text { Usually energy dependent } \\
\text { Flux against gradient }\end{array}$ & & \\
\hline Fluid phase & $\begin{array}{l}\text { Soluble molecules internalized with the vesicle volume } \\
\text { Nonsaturable, nonspecific dependent on solubility }\end{array}$ & Lucifer yellow & 145,146 \\
\hline Adsorptive & $\begin{array}{l}\text { Solute nonspecifically adsorbs to cell surface proteins/ } \\
\text { glycoproteins } \\
\text { Can be saturable and show competition, high capacity }\end{array}$ & gp-120 & 147 \\
\hline Receptor mediated & $\begin{array}{l}\text { Highly specific } \\
\text { High affinity, saturable, low capacity } \\
\text { Asymmetric }\end{array}$ & $\begin{array}{l}\text { Insulin } \\
\text { Vectors }\end{array}$ & 148 \\
\hline
\end{tabular}

CTAP $=$ D-Phe-Cys-Tyr-D-Trp-Arg-Thr-Per, Thr- $\mathrm{NH}_{2}$. 
have been reported for amino acids,${ }^{19}$ glucose,${ }^{20}$ and iron transferrin. ${ }^{21}$ Several saturable transport systems have also been reported for peptides, both influx and efflux. Influx (blood-to-brain) systems include leu-enkephalin, ${ }^{22,23}$ arginine vasopressin, ${ }^{24}$ and [D-penicillamine-2,5] enkephalin. ${ }^{25}$ Several efflux systems (brain-to-blood) have also been characterized, including a carrier-mediated efflux system for small N-Tyr peptides, ${ }^{26}$ the ATP binding cassette efflux pump P-glycoprotein (P-gp), ${ }^{27,28}$ multidrug resistance proteins, ${ }^{29}$ breast cancer resistance protein, ${ }^{30,31}$ organic anion transporters (OAT), ${ }^{32}$ organic anion-transporting polypeptides (OATP) ${ }^{33}$ and novel organic cation-transporters. ${ }^{34}$ These efflux transporters each have a large range of substrates, including various peptides that they can actively transport.

\section{STRATEGIES TO IMPROVE PEPTIDE DRUG BIOAVAILABILITY TO THE BRAIN}

A number of strategies have been used to improve bioavailability to the brain. Most of these rely on increasing the plasma half-life of the peptide, either by improving the metabolic stability or by reducing clearance from the plasma and brain. Metabolic stability and clearance can be improved by inhibiting proteolytic enzymes via masking enzyme cleavage sites, or by masking the peptides from active efflux transporters in the liver.

An example of using enzyme inhibition to improve brain delivery of a drug is seen with the use of L-amino acid decarboxylase inhibitors to improve L-DOPA delivery to the brain. L-DOPA, a precursor of dopamine used in the treatment of Parkinson's disease, uses the large neutral amino acid transporter (LNAA) to cross the BBB. ${ }^{35-37}$ Once in the brain it is converted to dopamine by ADD. However, ADD is in high concentration in the periphery as well, resulting in the rapid peripheral conversion of L-DOPA to dopamine, reducing CNS delivery and drug efficacy and substantially increasing side effects. However, coadministration of an ADD inhibitor that does not cross the BBB, promotes plasma half-life and delivery to the brain. Though a highly effective method for L-DOPA delivery, enzyme inhibition is not practical for most peptides, due to the large number of potential enzyme systems involved in degradation of each peptide drug candidate. Instead the focus has been on masking enzyme cleavage sites, via modification or addition of side chains that interfere with enzyme activity. A classic example of this strategy is the development of a family of enzymatically stable opioid analgesics based on the endogenous amino acid sequence for metenkephalin (Tyr-Gly-Gly-Phe-Met). The endogenous neuropeptide met-enkephalin, is rapidly enzymatically degraded in both brain and plasma ${ }^{38}\left(\mathrm{~T}_{1 / 2}<1 \mathrm{~min}\right)$. A number of strategies have been used to enhance the stability and thus the bioavailability of this peptide, in- cluding cyclization, ${ }^{12,39}$ halogenation, ${ }^{40}$ methylation, ${ }^{4,42}$ and cationization. ${ }^{43,44}$ The met-enkephalin analog, DPDPE, is a cyclized peptide containing D-penicillamine (D-Pen) at positions 2 and $5 .{ }^{45,46}$ The two D-Pens, form a disulfide bridge that conformationally constrains the peptide, leading to increased metabolic stability $\left(\mathrm{T}_{1 / 2}>500 \mathrm{~min}\right)$, bioavailability, and BBB permeability. ${ }^{47-49}$ In delivery studies with DPDPE, not only does DPDPE accumulate within the brain, it is also significantly cleared via the hepatic route. ${ }^{42,47,50}$ This is often an issue with cyclized peptides. Subsequent studies have shown that DPDPE is a substrate for a number of efflux pumps involved in billiary secretion including $\mathrm{Pgp}^{51-53}$ and OATP. ${ }^{54} \mathrm{~A}$ number of methods have been used to reduce the specificity of the efflux pumps to DPDPE and thus improve bioavailability. Polyethylene glycol (PEG) conjugation is one method shown to reduce efflux pump affinity of peptide drugs, to enhance peptide drug stability and circulation, while reducing immunogenicity, proteolysis, and clearance ${ }^{55,56}$ Addition of a 2000-Da PEG group to DPDPE significantly enhanced analgesia. ${ }^{42}$ The primary reason for the improved analgesia was shown to be a reduction in plasma clearance for the pegylated DPDPE, which results in a higher brain uptake over time. ${ }^{42}$ Pegylation also led to a shift away from hepatic clearance. ${ }^{42}$ The changes in DPDPE pharmacokinetics by pegylation were shown in part to be due to the masking of DPDPE from Pgp binding. ${ }^{42}$ This study demonstrates that increasing the bioavailability of a peptide can increase brain delivery, despite the reduction in blood-to-brain transport properties.

Although specific transport mechanisms are perhaps the best targets to focus CNS delivery strategies, the most simplistic route of enhancing the passive diffusion of peptides (i.e., increasing the lipophilicity) remains a viable method for increasing brain uptake. Lipophilicity has been shown to be a major determinant for the ability of a drug to diffuse across a membrane and remains one of the better tests for in vivo peptide permeability, ${ }^{57}$ although this is highly dependent on the peptides studied. ${ }^{58,59}$ Lipophilicity can be increased by reduction of hydrogen bonding potential and/or addition of lipophilic groups. Reduction of hydrogen bonding potential has been shown to increase BBB transport for a number of substances, including small peptides. ${ }^{60}$ Methylation can reduce the overall hydrogen bonding potential of peptides and increases membrane diffusion by enhancing lipophilicity. Dimethylation of the N-terminal Tyr of DPDPE lead to a significant increase in analgesia. ${ }^{61}$ In contrast, trimethylation of the Phe group of DPDPE significantly increased transport, without increasing analgesia. ${ }^{62}$ Interestingly, this study of four different isomers of $\left[\right.$ Trimethyl-Phe ${ }^{4}$ ] DPDPE showed differential effects on bioavailability, ligand-binding, and analgesia based solely on the methyl group position on the Phe benzene 
ring; only one isomer showed an increased transport, whereas the others had no effect, or decreased transport. ${ }^{62}$ This dramatically illustrates an important point for peptide modifications, that the site and type of modification are vital for both the improvement of delivery and maintenance of biological activity. It is also important (when considering larger peptides) to understand the intramolecular hydrogen bonding involved in the tertiary molecular structure. For example, biphalin, an opioid peptide containing two enkephalin sequences, has numerous potential hydrogen bonds, several of which are critical for maintaining the folding of the peptide within a given solution. ${ }^{63}$ An alteration in hydrogen bonding potential could alter the tertiary structure of the peptide and thus reduce its ability to interact with the opioid receptor. This could partially explain the loss of binding shown with the methylation of DPDPE. ${ }^{62}$ Despite multiple strategies to enhance lipophilicity, there are obvious limitations. Highly lipophilic drugs tend to be extensively plasma bound, may increase affinity for efflux transporters at the BBB, resulting in intraendothelial sequestration and are readily taken up in the periphery.

More recent studies have focused on targeting specific transport mechanisms either via site-directed vectors or synthetic routes. Some transport systems/sites that have been targeted include the LNAA, ${ }^{64}$ receptor-mediated endocytosis/transcytosis, ${ }^{65-68}$ and adsorptive endocytosis/transcytosis. ${ }^{69,70}$ For the purpose of this review, we will focus on two favored methods for improving brain delivery, the use of vectors and glycosylation.

\section{VECTOR-MEDIATED TRANSPORT}

Vectorial transport involves the conjugation of a peptide-drug to a targeting molecule/substance, which has affinity for characteristics or receptors of the target tissue, most often resulting in absorptive or receptor-mediated endocytosis. Vectors that have been used include cationized albumin, ${ }^{71}$ liposomes, ${ }^{72}$ nanoparticles ${ }^{73}$ and conjugation with monoclonal antibodies to receptors such as transferrin. ${ }^{67}$

Of these approaches, the use of the transferrin receptor has shown the most promise and has been used to transport several different classes of peptides across the BBB. The transferrin receptor is constituently expressed at the $\mathrm{BBB}^{21}$ at higher levels than other capillary beds ${ }^{74}$ and is involved in the transport of iron into the brain. The murine monoclonal antibody to the rat transferrin receptor, OX26, has been successfully used to increase brain uptake of proteins and peptides in a receptor- mediated manner. Friden and colleagues ${ }^{74}$ demonstrated that they could target the brain delivery of methotrexate using an OX26-methotrexate conjugate. Although OX26 is a nonpeptide, this study was an important first proof of the principle. The specific targeting of OX26 to the brain was confirmed by Pardridge ${ }^{67}$ showing that OX26 accumulated in the brain 18-fold higher than nonspecific IgG. Because the initial studies with OX26-methotrexate conjugates, several peptides have been investigated, including vasoactive intestinal peptide (VIP), ${ }^{75} \mathrm{BDNF}^{76}$ and epidermal growth factor (EGF) ${ }^{76}$ Each investigation resulted in increased brain uptake of the peptide in question. Interestingly, this methodology has also been used for immunoliposomes and gene delivery. ${ }^{77-79}$ The first peptide that showed good penetration of the BBB with antibody conjugation was VIP. Bickel et al. ${ }^{75}$ showed that administration of OX26 linked to VIP via a biotinavidin linker raised cerebral blood flow, while the biotinVIP alone did not. Unfortunately, peripheral administration of the OX26-VIP was only efficacious when given by intra carotid administration. The original avidin linkers resulted in rapid elimination due to their highly cationic nature. In a subsequent study the linker was changed to streptavidin, which is biologically neutral in nature. ${ }^{80}$ VIP-biotin conjugated to OX26-streptavidin increased blood flow after intravenous administration with a reduction in unwanted side effects in peripheral organs. ${ }^{80}$ An issue that can be a problem for delivery of peptides using antitransferrin receptor antibodies is the potential stearic inhibition of the peptide binding to the receptor or even the peptide interfering with the antibody binding. This issue has been addressed by the addition of polyethylene-glycol linkers. ${ }^{81}$

Antibody-peptide vectors have shown significant advantages in the treatment of acute disorders. In animal models of stroke an increase in the levels of BDNF mRNA is observed, starting approximately two hours after stroke commencement. ${ }^{82}$ The mRNA was observed predominantly in cells which have normal morphological appearance. ${ }^{82}$ Subsequent studies showed that administration of BDNF via an osmotic pump directly into the infarct following middle cerebral artery occlusion (MCAO), could lead to a significant reduction in infarct size. ${ }^{83}$ Studies in single allele BDNF knockout mice confirmed these findings. ${ }^{84}$ Like many other peptides, BDNF does not cross the BBB, which makes it an ideal candidate for conjugation to OX26. Initial studies with a BDNF-OX26 conjugate showed that there was indeed an increased delivery to the brain of intact BDNF. To test the potential of the conjugate for stroke treatment, the effect of BDNF-OX26 on a transient MCAO model was investigated. ${ }^{66}$ The administration of BDNF-OX26 directly after the ischemic incident followed by 6 further daily injections, prevented significant neuronal damage. In contrast, BDNF alone or OX26 alone did not produce any significant protection. ${ }^{66}$ These data indicate that the protective effect of the BDNF-OX26 conjugate is directly correlated to its ability to cross the BBB. Clinically, the time course of this study may not be relevant, as most stroke victims have a significant delay between 
symptom onset and treatment. Also, the model involved clamping the carotid arteries to produce a global "stroke," again not as common a situation clinically in humans. To investigate the effects of delayed treatment with BDNF-OX26 on MCAO, Zhang and Pardridge ${ }^{85}$ used the intraluminal thread model of MCAO. This model produces a smaller infarct in the middle cerebral artery region and is a more clinically viable model. The BDNF-OX26 conjugate was given either at the commencement of reperfusion or following $1 \mathrm{~h}$ of reperfusion. In both treatment paradigms, a significant neuroprotection was observed. ${ }^{85} \mathrm{~A}$ follow up study showed that the protective effect of BDNF-OX26 was both time (i.e., the sooner the conjugate is given after the infarct the better) and concentration dependent. ${ }^{86}$ It is thus apparent that this technology may be a useful method for delivering growth factors to ischemic brain regions during stroke, and could be adapted to other peptides/proteins. Other studies have shown that basic FGF conjugates may also be effective ${ }^{87}$ in stroke treatment.

One issue that should be considered when targeting a nutrient carrier such as the transferrin receptor is how this affects the transport of the native substrate. Although OX26 has been shown to bind to a region distant from the receptor binding site, ${ }^{21}$ Ueda and colleagues ${ }^{88}$ observed that pretreatment of animals with OX26 reduced Fe-transferrin delivery across the BBB by $30-40 \%$. Whether this reduction is prolonged, physiologically relevant or relevant to other anti-transferrin antibodies used has not been fully addressed. It does however offer evidence that this approach should be used with caution in a limited use or with potent peptides that only require limited delivery to the CNS.

\section{GLYCOSYLATION}

Glycosylation has shown significant potential for enhancing biodistribution of peptide-drugs to the CNS. The idea of glycosylation, as a mode of drug delivery, initially started through studies examining diabetes. It was noted that glycosylated proteins, produced by the Maillard reaction, had increased distribution to nervous tissue in both the periphery and brain. ${ }^{89,90}$ The chemical attachment of carbohydrate moieties to a protein (glycoprotein) or peptide (glycopeptide) produces changes in the molecular structure that, in turn, can have significant effects on the pharmacodynamic and pharmacokinetic properties of proteins and peptide hormones. ${ }^{91}$ Non-specific glycosylation was found to improve metabolic stability and increase activity of gastric inhibitory proteins. ${ }^{92-94}$ This strategy has been used to increase the half-life of erythropoietin, another glycoprotein, with at least one variant being approved by the Food and Drug Administration for the treatment of anemia. ${ }^{95}$

The increased stability induced by glycosylation has made it a focus for peptide drug examination / development. Glycosylation of small peptides has led to increase hydrophilicity, stability, and bioavailability. ${ }^{96-99}$ Additionally, glycosylation of opioid peptides has shown to enhance $\mathrm{BBB}$ penetration leading to increased pharmacological activity. ${ }^{97,98,100-102}$ BBB permeability studies of glycopeptides have indicated up to a three-fold increase in the rate of brain delivery, compared to the unglycosylated parent peptides. ${ }^{97,101,102}$ Evidence also suggests that the type of glycosylation (i.e., mono-, di-, tri-glycosylation) can alter tissue distribution patterns, ${ }^{103-105}$ BBB permeability, ${ }^{102}$ and peptide/receptor interactions. ${ }^{106,107}$

Peptides investigated to date include recombinant human erythropoietin, ${ }^{108}$ leptin, ${ }^{108}$ dermorphins ${ }^{98}$ and metenkephalin analogs. ${ }^{99}$ The first study on glycopeptide opioids focused on a cyclized met-enkephalin analog, [D-Cys-2,5] enkephalin (DCDCE). ${ }^{99}$ In this study the authors added a Ser $\beta$ D-glucose at various structural positions of the peptide and investigated receptor binding and analgesia following intravenous administration. The addition of the glyco group within the cyclized region of the peptide led to large decrease in binding to opioid receptors and no in vivo activity. In contrast, addition of the glycol group at position six led to only minor changes in receptor binding and a significant increase in analgesia following peripheral administration. ${ }^{99}$ The improved analgesia was related to a combination of increased metabolic stability and delivery to the brain potentially via a glucose transporter. Subsequent studies proved that there was indeed increased transport across the BBB, but not via an interaction with the glucose transporter. ${ }^{102,109}$ It is currently believed that the enhanced transport is due to adsorptive endocytosis. ${ }^{69}$ The studies by Polt and colleagues $^{99}$ highlight the importance of location of the glycosylation group on biological activity. Opioid enkephalin peptides require the alignment of the phenol rings of both the $\mathrm{Tyr}^{1}$ and $\mathrm{Phe}^{4}$ for maximal opioid receptor binding, placement of a Ser $\beta \mathrm{D}$-glucose between these groups reduced the binding to the $\mu$-opioid receptor from $30 \mathrm{~nm}$ to approximately 50,000 nM. Placement of the Ser $\beta \mathrm{D}$-glucose outside of the active region at position 6 , lead to $\mu$-opioid receptor binding of $53 \mathrm{~nm}$, only a minor change, ${ }^{99}$ indicating that the glycosylation did not affect the alignment of the Tyr and Phe groups. This was confirmed by NMR and molecular modeling, which showed that glycosylation at the $\operatorname{Ser}^{6}$ does not stearically affect the active region of the peptide, ${ }^{110}$ which is critically important in maintaining efficacy.

Since the initial studies on glycosylated enkephalin opioids a number of opioid analogs have been tested, the most promising of which are based on linear leu-enkephalin analogs. The monoglycosylated peptide Tyr-DThr-Gly-Phe-Leu-Ser ( $\beta$-D-glucose), produces analgesia after both central and peripheral administration with an 
A50 value comparable to that of morphine after IV administration. ${ }^{97}$ Surprisingly, it was shown that this peptide was more analgesically potent when given subcutaneously. ${ }^{97}$ Subsequent studies revealed that this glycopeptide had a higher metabolic stability in both plasma and serum than the parent peptide, ${ }^{101}$ double the brain penetration ${ }^{101}$ and the transport of the glycopeptide was reported to be saturable. ${ }^{101}$ These studies have therefore shown that glycosylation may be a useful tool for delivering small peptides to the CNS. Recent examinations have shown that opioid glycopeptides seem to be well tolerated, with minimal side effects. ${ }^{97,100}$ However, as of yet no chronic pharmacological or toxicological studies have been performed with these glycopeptide analgesics and much more research is required before a clinically viable candidate is available for treatment consideration.

\section{SUMMARY}

Peptides are a relatively untapped and potentially powerful therapeutic for disease prevention and treatment, yet as a group of drugs they suffer from numerous obstacles. Furthermore, the development of peptidedrugs, specific for CNS disorders, has historically been limited due to the BBB. Present technologies are advancing our ability to focus peptide drug delivery in manners previously unforeseen, with such concepts as specific antibody directed vectors and glycosylation, which not only enhance the pharmacological profile of these drugs, but can increase BBB transport into the brain in a regionally specific manner. The use of vector-mediated delivery shows continued promise in targeting peptides, as well as genes, with increasing degrees of success. This approach may prove ideal for chemotherapeutic applications, chronic CNS diseases in specific brain regions (i.e., Parkinson's), and for delivery of neuroprotective agents during acute disorders (i.e., stroke). Glycosylation has proven to be a useful methodology for enhancing biodistribution to the brain, through increased stability, reduced clearance, and improved BBB transport. Improving analgesia of opioid peptides is just one potential use of the glycosylation strategy. This approach may also prove highly useful in situations where prolonged administration of drugs is required, such as depression or chronic pain. The future of CNS focused peptide-drug delivery may likely be a composite of many of such strategies as the only limitation has become the imagination and creativity of the researcher.

Acknowledgments: This work was supported by National Institutes of Health Grants RO1 NS 42652, NS 39592, and DA 11271 (to T.P.D.) and RO1 DK 065003 and PO1 DA 006284 (to R.D.E.).

\section{REFERENCES}

1. Ooi GT, Herington AC. Recognition of insulin-like-growth-factor-binding proteins in serum and amniotic fluid by an antiserum against a low-molecular-mass insulin-like-growth-factor-inhibitor/binding protein. Biochem J 267:615-620, 1990.

2. Zapf J, Schmid C, Guler HP, et al. Regulation of binding proteins for insulin-like growth factors (IGF) in humans. Increased expression of IGF binding protein 2 during IGF I treatment of healthy adults and in patients with extrapancreatic tumor hypoglycemia. J Clin Invest 86:952-961, 1990.

3. Lalu K, Lampelo S, Nummelin-Kortelainen M, Vanha-Perttula T. Purification and partial characterization of aminopeptidase A from the serum of pregnant and non-pregnant women. Biochim Biophys Acta 789:324-333, 1984.

4. Hollenberg NK. Implications of species difference for clinical investigation: studies on the renin-angiotensin system. Hypertension 35:150-154, 2000.

5. Takenaga $\mathrm{N}$, Ishii $\mathrm{M}$, Nakajima $\mathrm{S}$, et al. In vivo metabolism of a new anticancer agent, 6-N-formylamino-12, 13-dihydro-1,11-dihydroxy-13-(beta-D-glucopyranosil)5H-indolo [2,3-a]pyrrolo [3,4c]carbazole-5,7(6H)-dione (NB-506) in rats and dogs: pharmacokinetics, isolation, identification, and quantification of metabolites. Drug Metab Dispos 27:205-212, 1999.

6. Decarie A, Raymond P, Gervais N, Couture R, Adam A. Serum interspecies differences in metabolic pathways of bradykinin and [des-Arg9]BK: influence of enalaprilat. Am J Physiol (Lond) 271: H1340-H1347, 1996.

7. Reese TS, Karnovsky MJ. Fine structural localization of a bloodbrain barrier to exogenous peroxidase. J Cell Biol 34:207-217, 1967.

8. Huber JD, Egleton RD, Davis TP. Molecular physiology and pathophysiology of tight junctions in the blood-brain barrier. Trends Neurosci 24:719-725, 2001.

9. Jones HC, Keep RF, Butt AM. The development of ion regulation at the blood-brain barrier. Prog Brain Res 91:123-131, 1992.

10. Brightman MW, Reese TS. Junctions between intimately apposed cell membranes in the vertebrate brain. J Cell Biol 40:648-677, 1969.

11. Arthur FE, Shivers RR, Bowman PD. Astrocyte-mediated induction of tight junctions in brain capillary endothelium: an efficient in vitro model. Brain Res 433:155-159, 1987.

12. Brownson EA, Abbruscato TJ, Gillespie TJ, Hruby VJ, Davis TP. Effect of peptidases at the blood brain barrier on the permeability of enkephalin. J Pharmacol Exp Ther 270:675-680, 1994.

13. Greene DL, Hau VS, Abbruscato TJ, et al. Enkephalin analog prodrugs: assessment of in vitro conversion, enzyme cleavage characterization and blood-brain barrier permeability. J Pharmacol Exp Ther 277:1366-1375, 1996.

14. Bausback HH, Churchill L, Ward PE. Angiotensin metabolism by cerebral microvascular aminopeptidase A. Biochem Pharmacol 37:155-160, 1988.

15. Churchill L, Bausback HH, Gerritsen ME, Ward PE. Metabolism of opioid peptides by cerebral microvascular aminopeptidase M. Biochim Biophys Acta 923:35-41, 1987.

16. Orte C, Lawrenson JG, Finn TM, Reid AR, Allt G. A comparison of blood-brain barrier and blood-nerve barrier endothelial cell markers. Anat Embryol (Berl) 199:509-517, 1999.

17. Orlowski M, Sessa G, Green JP. $\gamma$-Glutamyl transpeptidase in brain capillaries: possible site of a blood-brain barrier for amino acids. Science 184:66-68, 1974.

18. Nakazato H, Deguchi M, Fujimoto M, Fukushima H. Alkaline phosphatase expression in cultured endothelial cells of aorta and brain microvessels: induction by interleukin-6-type cytokines and suppression by transforming growth factor $\beta$ s. Life Sci 61:20652072, 1997.

19. Oldendorf WH, Szabo J Amino acid assignment to one of three blood-brain barrier amino acid carriers. Am J Physiol (Lond) 230:94-98, 1976.

20. Gjedde A. High- and low-affinity transport of D-glucose from blood to brain. J Neurochem 36:1463-1471, 1981.

21. Jefferies WA, Brandon MR, Hunt SV, Williams AF, Gatter KC, 
Mason DY. Transferrin receptor on endothelium of brain capillaries. Nature 312:162-163, 1984.

22. Zlokovic BV, Lipovac MN, Begley DJ, Davson H, Rakic L. Transport of leucine-enkephalin across the blood-brain barrier in the perfused guinea pig brain. J Neurochem 49:310-315, 1987.

23. Zlokovic BV, Mackic JB, Djuricic B, Davson H. Kinetic analysis of leucine-enkephalin cellular uptake at the luminal side of the blood-brain barrier of an in situ perfused guinea-pig brain. $J$ Neurochem 53:1333-1340, 1989.

24. Zlokovic BV, Hyman S, McComb JG, Lipovac MN, Tang G, Davson H. Kinetics of arginine-vasopressin uptake at the bloodbrain barrier. Biochim Biophys Acta 1025:191-198, 1990.

25. Thomas SA, Abbruscato TJ, Hruby VJ, Davis TP. The entry of [D-penicillamine2,5]enkephalin into the central nervous system: saturation kinetics and specificity. J Pharmacol Exp Ther 280: 1235-1240, 1997.

26. Banks WA, Kastin AJ, Ehrensing CA. Endogenous peptide TyrPro-Trp-Gly-NH2 (Tyr-W-MIF-1) is transported from the brain to the blood by peptide transport system-1. J Neurosci Res 35: 690-695, 1993

27. Rao VV, Dahlheimer JL, Bardgett ME, et al. Choroid plexus epithelial expression of MDR1 P glycoprotein and multidrug resistance-associated protein contribute to the blood-cerebrospinal-fluid drug-permeability barrier. Proc Natl Acad Sci USA 96: 3900-3905, 1999.

28. Thiebaut F, Tsuruo T, Hamada H, Gottesman MM, Pastan I, Willingham MC. Immunohistochemical localization in normal tissues of different epitopes in the multidrug transport protein P170: evidence for localization in brain capillaries and crossreactivity of one antibody with a muscle protein. $J$ Histochem Cytochem 37:159-164, 1989

29. Seetharaman S, Barrand MA, Maskell L, Scheper RJ. Multidrug resistance-related transport proteins in isolated human brain microvessels and in cells cultured from these isolates. J Neurochem 70:1151-1159, 1998.

30. Cooray HC, Blackmore CG, Maskell L, Barrand MA. Localisation of breast cancer resistance protein in microvessel endothelium of human brain. Neuroreport 13:2059-2063, 2002.

31. Eisenblatter T, Galla HJ. A new multidrug resistance protein at the blood-brain barrier. Biochem Biophys Res Commun 293:1273-1278, 2002.

32. Kusuhara H, Sekine T, Utsunomiya-Tate N, et al. Molecular cloning and characterization of a new multispecific organic anion transporter from rat brain. J Biol Chem 274:13675-13680, 1999.

33. Gao B, Stieger B, Noe B, Fritschy JM, Meier PJ. Localization of the organic anion transporting polypeptide 2 (Oatp2) in capillary endothelium and choroid plexus epithelium of rat brain. $J$ Histochem Cytochem 47:1255-1264, 1999.

34. Kido Y, Tamai I, Ohnari A, et al. Functional relevance of carnitine transporter OCTN2 to brain distribution of L-carnitine and acetyl-L-carnitine across the blood-brain barrier. J Neurochem 79:959-969, 2001.

35. Wade LA, Katzman R. Rat brain regional uptake and decarboxylation of L-DOPA following carotid injection. Am J Physiol (Lond) 228:352-359, 1975.

36. Wade LA, Katzman R. Synthetic amino acids and the nature of L-DOPA transport at the blood-brain barrier. J Neurochem 25: 837-842, 1975 .

37. Wade LA, Katzman R. 3-O-Methyldopa uptake and inhibition of L-dopa at the blood-brain barrier. Life Sci 17:131-136, 1975.

38. Dupont A, Cusan L, Garon M, Alvarado-Urbina G, Labrie F. Extremely rapid degradation of $[3 \mathrm{H}]$ methionine-enkephalin by various rat tissues in vivo and in vitro. Life Sci 21:907-914, 1977.

39. Gudmundsson OS, Vander Velde DG, Jois SD, Bak A, Siahaan TJ, Borchardt RT. The effect of conformation of the acyloxyalkoxy-based cyclic prodrugs of opioid peptides on their membrane permeability. J Pept Res 53:403-413, 1999.

40. Gentry CL, Egleton RD, Gillespie T, et al. The effect of halogenation on blood-brain barrier permeability of a novel peptide drug. Peptides 20:1229-1238, 1999.

41. Brewster D, Dettmar PW, Metcalf G. Biologically stable analogues of TRH with increased neuropharmacological potency. Neuropharmacology 20:497-503, 1981.
42. Witt KA, Huber JD, Egleton RD, et al. Pharmacodynamic and pharmacokinetic characterization of poly(ethylene glycol) conjugation to met-enkephalin analog [D-Pen2, D-Pen5]-enkephalin (DPDPE). J Pharmacol Exp Ther 298:848-856, 2001.

43. Boado RJ, Pardridge WM. Complete inactivation of target mRNA by biotinylated antisense oligodeoxynucleotide-avidin conjugates. Bioconjug Chem 5:406-410, 1994.

44. Bickel U, Yoshikawa T, Pardridge WM. Delivery of peptides and proteins through the blood-brain barrier. Adv Drug Deliv Rev 46:247-279, 2001.

45. Mosberg HI, Hurst R, Hruby VJ, et al. Bis-penicillamine enkephalins possess highly improved specificity toward $\delta$ opioid receptors. Proc Natl Acad Sci USA 80:5871-5874, 1983.

46. Mosberg HI, Hurst R, Hruby VJ, et al. Cyclic penicillamine containing enkephalin analogs display profound $\delta$ receptor selectivities. Life Sci 33 [Suppl 1] :447-450, 1983.

47. Weber SJ, Greene DL, Hruby VJ, Yamamura HI, Porreca F, Davis TP. Whole body and brain distribution of $[3 \mathrm{H}]$ cyclic [D-Pen2,D-Pen5] enkephalin after intraperitoneal, intravenous, oral and subcutaneous administration. J Pharmacol Exp Ther 263:1308-1316, 1992.

48. Weber SJ, Abbruscato TJ, Brownson EA, et al. Assessment of an in vitro blood-brain barrier model using several [Met5] enkephalin opioid analogs. J Pharmacol Exp Ther 266:1649-1655, 1993.

49. Williams SA, Abbruscato TJ, Hruby VJ, Davis TP. Passage of a $\delta$-opioid receptor selective enkephalin, [D-penicillamine2,5] enkephalin, across the blood-brain and the blood-cerebrospinal fluid barriers. J Neurochem 66:1289-1299, 1996.

50. Chen C, Pollack GM. Extensive biliary excretion of the model opioid peptide [D-PEN2,5] enkephalin in rats. Pharm Res 14:345350, 1997.

51. Dagenais C, Graff CL, Pollack GM. Variable modulation of opioid brain uptake by P-glycoprotein in mice. Biochem Pharmacol 67:269-276, 2004.

52. Chen C, Pollack GM. Altered disposition and antinociception of [D-penicillamine(2,5)] enkephalin in mdr1a-gene-deficient mice. J Pharmacol Exp Ther 287:545-552, 1998.

53. King M, Su W, Chang A, Zuckerman A, Pasternak GW. Transport of opioids from the brain to the periphery by P-glycoprotein: peripheral actions of central drugs. Nat Neurosci 4:268-274, 2001.

54. Gao B, Hagenbuch B, Kullak-Ublick GA, Benke D, Aguzzi A, Meier PJ. Organic anion-transporting polypeptides mediate transport of opioid peptides across blood-brain barrier. J Pharmacol Exp Ther 294:73-79, 2000.

55. Reddy KR. Controlled-release, pegylation, liposomal formulations: new mechanisms in the delivery of injectable drugs. Ann Pharmacother 34:915-923, 2000.

56. Delgado C, Francis GE, Fisher D. The uses and properties of PEG-linked proteins. Crit Rev Ther Drug Carrier Syst 9:249_ 304, 1992.

57. Banks WA, Kastin AJ. Peptides and the blood-brain barrier: lipophilicity as a predictor of permeability. Brain Res Bull 15: 287-292, 1985.

58. Buchwald P, Bodor N. Octanol-water partition: searching for predictive models. Curr Med Chem 5:353-380, 1998.

59. Buchwald P, Bodor N. Octanol-water partition of nonzwitterionic peptides: predictive power of a molecular size-based model. Proteins 30:86-99, 1998.

60. Chikhale EG, Ng KY, Burton PS, Borchardt RT. Hydrogen bonding potential as a determinant of the in vitro and in situ bloodbrain barrier permeability of peptides. Pharm Res 11:412-419, 1994.

61. Hansen DW Jr, Stapelfeld A, Savage MA, et al. Systemic analgesic activity and $\delta$-opioid selectivity in [2,6-dimethyl-Tyr1,DPen2,D-Pen5]enkephalin. J Med Chem 35:684-687, 1992.

62. Witt KA, Slate CA, Egleton RD, et al. Assessment of stereoselectivity of trimethylphenylalanine analogues of $\delta$-opioid [D-Pen(2),D-Pen(5)]-enkephalin. J Neurochem 75:424-435, 2000.

63. Flippen-Anderson JL, Deschamps JR, George C, Hruby VJ, Misicka A, Lipkowski AW. Crystal structure of biphalin sulfate: a multireceptor opioid peptide. J Pept Res 59:123-133, 2002. 
64. Abbruscato TJ, Thomas SA, Hruby VJ, Davis TP. Brain and spinal cord distribution of biphalin: correlation with opioid receptor density and mechanism of CNS entry. J Neurochem 69: 1236-1245, 1997

65. Wu D, Song BW, Vinters HV, Pardridge WM. Pharmacokinetics and brain uptake of biotinylated basic fibroblast growth factor conjugated to a blood-brain barrier drug delivery system. J Drug Target 10:239-245, 2002.

66. Wu D, Pardridge WM. Neuroprotection with noninvasive neurotrophin delivery to the brain. Proc Natl Acad Sci USA 96:254259, 1999.

67. Pardridge WM, Buciak JL, Friden PM. Selective transport of an anti-transferrin receptor antibody through the blood-brain barrier in vivo. J Pharmacol Exp Ther 259:66-70, 1991.

68. Friden PM, Walus LR, Watson P, et al. Blood-brain barrier penetration and in vivo activity of an NGF conjugate. Science 259: 373-377, 1993.

69. Palian MM, Boguslavsky VI, O’Brien DF, Polt R. Glycopeptidemembrane interactions: glycosyl enkephalin analogues adopt turn conformations by NMR and CD in amphipathic media. $J \mathrm{Am}$ Chem Soc 125:5823-5831, 2003.

70. Tamai I, Sai Y, Kobayashi H, Kamata M, Wakamiya T, Tsuji A. Structure-internalization relationship for adsorptive-mediated endocytosis of basic peptides at the blood-brain barrier. $J$ Pharmacol Exp Ther 280:410-415, 1997.

71. Kumagai AK, Eisenberg JB, Pardridge WM. Absorptive-mediated endocytosis of cationized albumin and a $\beta$-endorphin-cationized albumin chimeric peptide by isolated brain capillaries. Model system of blood-brain barrier transport. J Biol Chem 262: 15214-15219, 1987.

72. Chen D, Li QT, Lee KH. Antinociceptive activity of liposomeentrapped calcitonin by systemic administration in mice. Brain Res 603:139-142, 1993.

73. Kreuter J, Alyautdin RN, Kharkevich DA, Ivanov AA. Passage of peptides through the blood-brain barrier with colloidal polymer particles (nanoparticles). Brain Res 674:171-174, 1995.

74. Friden PM, Walus LR, Musso GF, Taylor MA, Malfroy B, Starzyk RM. Anti-transferrin receptor antibody and antibody-drug conjugates cross the blood-brain barrier. Proc Natl Acad Sci USA 88:4771-4775, 1991.

75. Bickel U, Yoshikawa T, Landaw EM, Faull KF, Pardridge WM. Pharmacologic effects in vivo in brain by vector-mediated peptide drug delivery. Proc Natl Acad Sci USA 90:2618-2622, 1993.

76. Pardridge WM, Kang YS, Buciak JL. Transport of human recombinant brain-derived neurotrophic factor (BDNF) through the rat blood-brain barrier in vivo using vector-mediated peptide drug delivery. Pharm Res 11:738-746, 1994.

77. Shi N, Pardridge WM. Noninvasive gene targeting to the brain. Proc Natl Acad Sci USA 97:7567-7572, 2000.

78. Shi N, Boado RJ, Pardridge WM. Receptor-mediated gene targeting to tissues in vivo following intravenous administration of pegylated immunoliposomes. Pharm Res 18:1091-1095, 2001.

79. Shi N, Zhang Y, Zhu C, Boado RJ, Pardridge WM. Brain-specific expression of an exogenous gene after i.v. administration. Proc Natl Acad Sci USA 98:12754-12759, 2001.

80. Wu D, Pardridge WM. Central nervous system pharmacologic effect in conscious rats after intravenous injection of a biotinylated vasoactive intestinal peptide analog coupled to a blood-brain barrier drug delivery system. J Pharmacol Exp Ther 279:77-83, 1996.

81. Deguchi Y, Kurihara A, Pardridge WM. Retention of biologic activity of human epidermal growth factor following conjugation to a blood-brain barrier drug delivery vector via an extended poly(ethylene glycol) linker. Bioconjug Chem 10:32-37, 1999.

82. Comelli MC, Guidolin D, Seren MS, et al. Time course, localization and pharmacological modulation of immediate early inducible genes, brain-derived neurotrophic factor and trkB messenger RNAs in the rat brain following photochemical stroke. Neuroscience 55:473-490, 1993.

83. Yamashita K, Wiessner C, Lindholm D, Thoenen H, Hossmann KA. Post-occlusion treatment with BDNF reduces infarct size in a model of permanent occlusion of the middle cerebral artery in rat. Metab Brain Dis 12:271-280, 1997.
84. Endres M, Fan G, Hirt L, et al. Ischemic brain damage in mice after selectively modifying BDNF or NT4 gene expression. J Cereb Blood Flow Metab 20:139-144, 2000.

85. Zhang Y, Pardridge WM. Neuroprotection in transient focal brain ischemia after delayed intravenous administration of brain-derived neurotrophic factor conjugated to a blood-brain barrier drug targeting system. Stroke 32:1378-1384, 2001.

86. Zhang Y, Pardridge WM. Conjugation of brain-derived neurotrophic factor to a blood-brain barrier drug targeting system enables neuroprotection in regional brain ischemia following intravenous injection of the neurotrophin. Brain Res 889:49-56, 2001

87. Song BW, Vinters HV, Wu D, Pardridge WM. Enhanced neuroprotective effects of basic fibroblast growth factor in regional brain ischemia after conjugation to a blood-brain barrier delivery vector. J Pharmacol Exp Ther 301:605-610, 2002.

88. Ueda F, Raja KB, Simpson RJ, Trowbridge IS, Bradbury MW. Rate of 59Fe uptake into brain and cerebrospinal fluid and the influence thereon of antibodies against the transferrin receptor. J Neurochem 60:106-113, 1993.

89. Poduslo JF, Curran GL. Increased permeability across the bloodnerve barrier of albumin glycated in vitro and in vivo from patients with diabetic polyneuropathy. Proc Natl Acad Sci USA 89:2218-2222, 1992.

90. Poduslo JF, Curran GL. Glycation increases the permeability of proteins across the blood-nerve and blood-brain barriers. Brain Res Mol Brain Res 23:157-162, 1994

91. Lis H, Sharon N. Protein glycosylation. Structural and functional aspects. Eur J Biochem 218:1-27, 1993.

92. O'Harte FP, Mooney MH, Flatt PR. NH2-terminally modified gastric inhibitory polypeptide exhibits amino-peptidase resistance and enhanced antihyperglycemic activity. Diabetes 48:758-765, 1999.

93. O'Harte FP, Mooney MH, Kelly CM, Flatt PR. Improved glycaemic control in obese diabetic ob/ob mice using N-terminally modified gastric inhibitory polypeptide. J Endocrinol 165:639648, 2000.

94. O'Harte FP, Mooney MH, Lawlor A, Flatt PR. N-terminally modified glucagon-like peptide-1(7-36) amide exhibits resistance to enzymatic degradation while maintaining its antihyperglycaemic activity in vivo. Biochim Biophys Acta 1474:13-22, 2000.

95. Macdougall IC, Gray SJ, Elston O, et al. Pharmacokinetics of novel erythropoiesis stimulating protein compared with epoetin alfa in dialysis patients. J Am Soc Nephrol 10:2392-2395, 1999.

96. Albert R, Marbach P, Bauer W, et al. SDZ CO 611: a highly potent glycated analog of somatostatin with improved oral activity. Life Sci 53:517-525, 1993.

97. Bilsky EJ, Egleton RD, Mitchell SA, et al. Enkephalin glycopeptide analogues produce analgesia with reduced dependence liability. J Med Chem 43:2586-2590, 2000.

98. Negri L, Lattanzi R, Tabacco F, Scolaro B, Rocchi R. Glycodermorphins: opioid peptides with potent and prolonged analgesic activity and enhanced blood-brain barrier penetration. BrJ Pharmacol 124:1516-1522, 1998.

99. Polt R, Porreca F, Szabo LZ, et al. Glycopeptide enkephalin analogues produce analgesia in mice: evidence for penetration of the blood-brain barrier. Proc Natl Acad Sci USA 91:7114-7118, 1994.

100. Elmagbari NO, Egleton RD, Palian M, et al. Antinociceptive structure-activity studies with enkephalin-based opioid glycopeptides. J Pharmacol Exp Ther 311:290-297, 2004.

101. Egleton RD, Mitchell SA, Huber JD, Palian MM, Polt R, Davis TP. Improved blood-brain barrier penetration and enhanced analgesia of an opioid peptide by glycosylation. J Pharmacol Exp Ther 299:967-972, 2001.

102. Egleton RD, Mitchell SA, Huber JD, et al. Improved bioavailability to the brain of glycosylated Met-enkephalin analogs. Brain Res 881:37-46, 2000.

103. Susaki H, Suzuki K, Yamada H, Okuno S, Watanabe HK. Renal targeting of arginine-vasopressin by modification with carbohydrates at the tyrosine side chain. Biol Pharm Bull 22:1094-1098, 1999. 
104. Suzuki K, Susaki H, Okuno S, Yamada H, Watanabe HK, Sugiyama Y. Specific renal delivery of sugar-modified low-molecular-weight peptides. J Pharmacol Exp Ther 288:888-897, 1999.

105. Suzuki K, Susaki H, Okuno S, Sugiyama Y. Renal drug targeting using a vector "alkylglycoside." J Pharmacol Exp Ther 288:5764, 1999.

106. Sargent DF, Bean JW, Schwyzer R. Conformation and orientation of regulatory peptides on lipid membranes. Key to the molecular mechanism of receptor selection. Biophys Chem 31:183-193, 1988.

107. Palian MM, Polt R. Lipo $\alpha$-amino- $\beta$-hydroxy acids and O-linked glycosides: building blocks for ceramyl and glycosphingoyl peptides. J Org Chem 66:7178-7183, 2001.

108. Elliott S, Lorenzini T, Asher S, et al. Enhancement of therapeutic protein in vivo activities through glycoengineering. Nat Biotechnol 21:414-421, 2003.

109. Williams SA, Abbruscato TJ, Szabo J, Polt R, Hruby VJ, Davis TP. The effect of glycosylation on the uptake of an enkephalin analogue into the central nervous system. In: Advances in behavioural biology: biology and physiology of the blood-brain barrier. New York: Plenum, 56:69-78, 1996.

110. Kriss CT, Lou B-S, Szabo J, Mitchell SA, Hruby VJ, Polt R. Enkephalin based drug design: conformational analysis of Olinked glycopeptides by NMR and molecular modeling. Tetrahedron Asymmetry 11:9-25, 2000.

111. Gentilucci L. New trends in the development of opioid peptide analogues as advanced remedies for pain relief. Curr Top Med Chem 4:19-38, 2004.

112. King TE, Barr GA. Functional development of neurokinin peptides substance P and neurokinin A in nociception. Neuroreport 14:1603-1607, 2003.

113. Elliott PJ, Krause JE, Cuello AC. Diminished nociceptive response in mice following immunization with neurokinins. Peptides 10:69-71, 1989.

114. Strohle A, Holsboer F. Stress responsive neurohormones in depression and anxiety. Pharmacopsychiatry [Suppl 36]:S207S214, 2003.

115. Claes SJ. Corticotropin-releasing hormone $(\mathrm{CRH})$ in psychiatry: from stress to psychopathology. Ann Med 36:50-61, 2004.

116. Datar P, Srivastava S, Coutinho E, Govil G. Substance P: structure, function, and therapeutics. Curr Top Med Chem 4:75-103, 2004.

117. Balasubramaniam A. Clinical potentials of neuropeptide $Y$ family of hormones. Am J Surg 183:430-434, 2002.

118. Solbrig MV, Koob GF. Epilepsy, CNS viral injury and dynorphin. Trends Pharmacol Sci 25:98-104, 2004.

119. Binaschi A, Bregola G, Simonato M. On the role of somatostatin in seizure control: clues from the hippocampus. Rev Neurosci 14:285-301, 2003.

120. Lim KC, Lim ST, Federoff HJ. Neurotrophin secretory pathways and synaptic plasticity. Neurobiol Aging 24:1135-1145, 2003.

121. Russo-Neustadt A. Brain-derived neurotrophic factor, behavior, and new directions for the treatment of mental disorders. Semin Clin Neuropsychiatry 8:109-118, 2003.

122. Bjorbaek C, Kahn BB. Leptin signaling in the central nervous system and the periphery. Recent Prog Horm Res 59:305-331, 2004.

123. Gale SM, Castracane VD, Mantzoros CS. Energy homeostasis, obesity and eating disorders: recent advances in endocrinology. $J$ Nutr 134:295-298, 2004.

124. Held K, Kunzel H, Ising M, et al. Treatment with the CRH1receptor-antagonist R121919 improves sleep-EEG in patients with depression. J Psychiatr Res 38:129-136, 2004.

125. Semkova I, Krieglstein J Neuroprotection mediated via neurotrophic factors and induction of neurotrophic factors. Brain Res Brain Res Rev 30:176-188, 1999.

126. Evangelopoulos ME, Weis J, Kruttgen A. Neurotrophin effects on neuroblastoma cells: correlation with trk and p75NTR expression and influence of Trk receptor bodies. J Neurooncol 66:101-110, 2004.
127. Denkins Y, Reiland J, Roy M, et al. Brain metastases in melanoma: roles of neurotrophins. Neuro-oncol 6:154-165, 2004.

128. Bertler A, Falck B, Owman C, Rosengrenn E. The localization of monoaminergic blood-brain barrier mechanisms. Pharmacol Rev 18:369-385, 1966.

129. Minn A, Ghersi-Egea JF, Perrin R, Leininger B, Siest G. Drug metabolizing enzymes in the brain and cerebral microvessels. Brain Res Brain Res Rev 16:65-82, 1991.

130. Gerhart DZ, Drewes LR. Butyrylcholinesterase in pericytes associated with canine brain capillaries. Cell Tissue Res 247:533536, 1987.

131. Chen ZR, Irvine RJ, Bochner F, Somogyi AA. Morphine formation from codeine in rat brain: a possible mechanism of codeine analgesia. Life Sci 46:1067-1074, 1990.

132. Perrin R, Minn A, Ghersi-Egea JF, Grassiot MC, Siest G. Distribution of cytochrome P450 activities towards alkoxyresorufin derivatives in rat brain regions, subcellular fractions and isolated cerebral microvessels. Biochem Pharmacol 40:2145-2151, 1990.

133. Granberg L, Ostergren A, Brandt I, Brittebo EB. CYP1A1 and CYP1B1 in blood-brain interfaces: CYP1A1-dependent bioactivation of 7,12-dimethylbenz(a)anthracene in endothelial cells. Drug Metab Dispos 31:259-265, 2003.

134. Ghersi-Egea JF, Leninger-Muller B, Suleman G, Siest G, Minn A. Localization of drug-metabolizing enzyme activities to bloodbrain interfaces and circumventricular organs. J Neurochem 62: 1089-1096, 1994.

135. Kowaloff H, Gavras H, Brecher P. Reninlike enzymatic activity in the cerebral microvessels of the rat. Am J Physiol (Lond) 238:H384-H388, 1980.

136. Brecher P, Tercyak A, Gavras H, Chobanian AV. Peptidyl dipeptidase in rabbit brain microvessels. Biochim Biophys Acta 526: 537-546, 1978

137. Benuck M, Berg MJ, Marks N. Met-enkephalin-Arg6-Phe7 metabolism: conversion to Met-enkephalin by brain and kidney dipeptidyl carboxypeptidases. Biochem Biophys Res Commun 99: 630-636, 1981

138. Solhonne B, Gros C, Pollard H, Schwartz JC. Major localization of aminopeptidase $\mathrm{M}$ in rat brain microvessels. Neuroscience 22:225-232, 1987.

139. Song L, Wilk E, Wilk S, Healy DP. Localization of immunoreactive glutamyl aminopeptidase in rat brain. I. Association with cerebral microvessels. Brain Res 606:286-294, 1993.

140. Vijayaraghavan J, Scicli AG, Carretero OA, Slaughter C, Moomaw C, Hersh LB. The hydrolysis of endothelins by neutral endopeptidase 24.11 (enkephalinase). J Biol Chem 265:1415014155,1990

141. Molineaux CJ, Ayala JM. An inhibitor of endopeptidase-24.15 blocks the degradation of intraventricularly administered dynorphins. J Neurochem Aug 55:611-618, 1990.

142. Black KL, Baba T, Pardridge WM. Enzymatic barrier protects brain capillaries from leukotriene C4. J Neurosurg 81:745-751, 1994.

143. Johnson MD, Anderson BD. Localization of purine metabolizing enzymes in bovine brain microvessel endothelial cells: an enzymatic blood-brain barrier for dideoxynucleosides? Pharm Res 13:1881-1886, 1996.

144. Abbruscato TJ, Thomas SA, Hruby VJ, Davis TP. Blood-brain barrier permeability and bioavailability of a highly potent and $\mu$-selective opioid receptor antagonist, CTAP: comparison with morphine. J Pharmacol Exp Ther 280:402-409, 1997.

145. Guillot FL, Audus KL. Angiotensin peptide regulation of fluidphase endocytosis in brain microvessel endothelial cell monolayers. J Cereb Blood Flow Metab 10:827-834, 1990.

146. Guillot FL, Audus KL, Raub TJ. Fluid-phase endocytosis by primary cultures of bovine brain microvessel endothelial cell monolayers. Microvasc Res 39:1-14, 1990.

147. Banks WA, Kastin AJ, Akerstrom V. HIV-1 protein gp120 crosses the blood-brain barrier: role of adsorptive endocytosis. Life Sci 61:PL119-PL125, 1997.

148. Duffy KR, Pardridge WM. Blood-brain barrier transcytosis of insulin in developing rabbits. Brain Res 420:32-38, 1987. 